\title{
Discussion on Education Management for College Students under New Situation
}

\author{
Qiuju Zeng \\ School of Art Design \\ Huanghe Science and Technology College \\ Zhengzhou, Henan, China 450063
}

\begin{abstract}
Education management for college students is an important part of the overall work of the school. The enrollment expansion of colleges for years makes students' overall quality uneven. Under the influence by various factors such as overall social environment and the rapid development of higher education, some outstanding problems of education management are to be solved. This paper tries to discuss the countermeasures and suggestions for education management for college students under new situation.
\end{abstract}

Keywords-education countermeasures; colleges

management;

problems;

\section{INTRODUCTION}

Student education management is a very important aspect in college management, which is conducive to maintain the stability and development of the school as well as to improve its school-running quality. With the deepening of the reform of educational system, there have been some new problems in the education management for college students, which have put forward new requirements for administrators.

\section{PROBLEMS OF THE EdUCATION MANAGEMENT FOR COLLEGE STUdeNTS}

\section{A. Problems of the Education Management for College Students Brought by Society, Family Environment and Educational Reform}

Currently, education management for college students has ushered in new challenges. $98 \%$ of the students are the only child in their family. With the profound influence by various factors such as the overall social environment, market economy and new media, college students' thoughts, demands and their outlook on values tend to be diversified.

- A considerable number of students have accustomed to the care from their parents and peers, with few opportunities to take care of others and lack of the gratitude consciousness. Their life is smooth without hardship and tribulations. They have dependant opinion, weak collective spirit, apathy, poor ability to withstand frustration, and they are indifferent.

- In the era of new media popularization, smart phones, WeChat and MicroBlog have become the main communication tools of college students, which have brought diversified adverse effects to the students: rumors resulted by unfounded remarks, human flesh search without knowing the truth, the prevailing follow-up posting, which have infringed the human rights to some extent, and some college students are addicted to the game, unwilling to listen to the class, and so on.

- The enrollment expansion for years, high tuition fees, living and learning pressure and employment competition have resulted in more and more college students having difficulties in learning, economy and psychology.

- $\quad$ There are many other problems hard to prevent, such as, public security problems surrounding new campus of the colleges; personal security issues caused by the personal safety of married college students off campus caused by renting house off-campus by the married college students, some students conduct extreme behavior and break the law due to their falling out of love.

\section{B. Problems Brought by the Colleges' Own Management System}

1) Superficial education management: All aspects of the work involving students' learning and life fall on the student management. The current working mechanism and contents is too complex, resulting in the student administrators struggling with the work assigned by various departments, and having difficulties in taking time to offer targeted cultivation and personalized education in terms of students' learning interest, practical ability, innovative spirit and other comprehensive qualities and abilities. "They are busy all day along from getting up till going to bed". Most of the work is the trivial routine work. So the administrators almost have no energy to pay attention to students' ideological trends, assistance to the vulnerable groups and the research on student working law, making the education management for students superficial, let alone meticulous management.

2) Administrators are inefficient: In the process of students' growing up, the effectiveness of student administers' management education is worthy of reflection. In other words, student administers receive most of the tasks 
passively, they go to the place where the problems take place to solve them, and they are more like the firemen and palliatives. They do less about the work such as helping students to cope with difficulties starting from students' actual difficulties, taking initiative to mobilize students' enthusiasm, as well as the work about how to better improve students' overall quality, and how to develop students' potential to a greater degree. The empty preaching makes students disgusted, resulting in ineffective ideological and political education. And there is less humanistic concern and personalized psychological counseling that meet students' emotional needs, restricting the development of students' comprehensive quality.

3) Problems exist in education management method: In traditional administrative management education for students, there is more moralizing from teachers with less service and guidance, resulting in the teacher-student relationship is not very harmonious, and even they do not understand each other. From the author's 10 years of front-line experience about student education management, there is more management from teachers, counselors and dorm administrators with fewer services and education, resulting in difficulties to form the mentor teacher-student relationship in true sense. They often habitually attribute various issues among students to ideological problems, and sometimes they teach all the students regarding one problem. Over time, students cannot get satisfied reply and solution regarding the problems they concern, educators' working effectiveness will be greatly reduced, and even if they have made all efforts, students are not satisfied. As the roles of parents, service providers, counselors and management educators are acted by one person, he/she will praise or criticize according to his/her own will. If things continue this way, students will not trust him/her, and the administrator also has difficulty in being a service provider and a friend of equality.

4) Systematicness, continuity and coordination of education management are not strong: The current student education management is still the palliative, and the "fireman" type working pattern has failed to be changed, resulting in certain discontinuity in student education management. A considerable number of students think the management education for students is not satisfactory, thinking it is a practice of formalism. For example, upon the completion of inspections of such places as student apartments, lecture theaters, stadiums and public health areas, students start to throw rubbish while they are walking. The student education management hasn't been normalized, so it is difficult for students to form a good habit. The reason is that relevant departments of the school have failed to recognize the importance of student education and management from the height of cultivating high quality talents truly. They tend to resolve local problems, complete individual task and cope with working inspection, which cannot be consistent with the high-quality education.
5) Student education administrators' professional level cannot meet the needs of new situation: With the continuous progress of society and the rapid development of new media in the campus, student education management should be more thorough, comprehensive and humane. This requires the student administrators to grasp profound basic knowledge and advanced management tools. Because the school has failed to pay enough attention to student education management with the lack of effective incentive mechanism, student administrators appear to be burnout with low professional identity and weak sense of belonging. In addition, in the information society, it is convenient for students to master knowledge. There are few opportunities for student administrators to investigate and be trained outside school. Thus their professional ability cannot meet the needs for the development of student work. Facing the widely used new media, education administrators shall strengthen their sense of lifelong learning, as well as improve their professional ability and the ability to work, so as to meet the needs of rapid social development.

6) Lack of unified understanding of student education management: The faculties have no unified understanding toward student education management. Many teachers think that their task is to teach or conduct a subject or write a paper, while not regarding educating as their fundamental task from the heart and they only teach, but not educate; the personnel at operation office staff are also indifferent to students' just demand, which is contrary to colleges' education law of "overall education and whole-process education". Some people even hold the opinion that education management for students shall be done by the counselors and secretary, various departments only perform their own duties, and the atmosphere of "whole staff education awareness" hasn't been formed.

\section{STRENGTHEN COUNTERMEASURES FOR COLLEGE}

\section{STUdENT EDUCATION MANAGEMENT IN THE NEW ERA}

As for the education management for college students, facing new social development situation, new demand for education development as well as the new situations and new problems appear in student management, student administrators are exploring continuously, to seek the best solutions. The author has proposed some suggestions and countermeasures in combination with many years of working experience.

\section{A. Change Concept, Unify Thinking, Strengthen and Improve the Understanding of Education Management for College Students}

The education management for college students shall not rely on student affairs personnel such as the counselors. The actual effect can only be received by earnestly implementing the educational policy of "educating by teaching, servicing and managing", generating the linked effects of various units and making a concerted efforts of the education management for students. To this end, we need to update the concepts of 
education, advance with the times, to truly combine education and management, and transform from management to education, guidance and service. College leaders should correct the concept of education, and fully recognize the urgency and importance of education and management for students from the point of cultivating socialist qualified builders and reliable successors, as well as earnestly take the effective measures. Only by sufficiently recognizing the ideological understanding, can the initiative and effectiveness of education management be strengthened, and the moral education resultant force can be formed better. In order to promote the improvement of student education management and provide a powerful guarantee, so as to promote improvement of college students' overall quality comprehensively.

\section{B. Establish a Scientific, Standardized and Perfect Student Work System}

Modern management believes that the system is necessary for organization of work and obtaining actual effect. The college in new era will be one without "fence". Due to the need of rights and interests between college individuals, as well as between individual and the school, it is required to use law and rules and regulations to regulate and adjust the relationship between various subjects for student work. To educate and manage college students by law is the task of higher education, and the guiding concept for college students' work. As a result, to establish a set of scientific, standardized and complete rules and regulations of student work is the need for education development. Various colleges shall formulate the complete rules and regulations with strong operability as per relevant provisions of national law and according to their own actual situation, to regulate students' behavior and conduct the effective management. For instance, the establishment of the gradually-perfect college students' credit archives system has played a good role in education management for college students, and such management system has achieved the organic combination of students' self-discipline and the discipline by others. With such normative and complete system, students will understand what the school asks them to do and how to do, and be well aware of the consequences of avoiding discipline, thus to regulate their own behavior. In addition, the establishment of scientific, standardized and complete rules and regulation for student work will enable education administrators to have rules to follows, which has brought great convenience to work.

\section{Strengthen the Construction of College Student Education Management Team and Cultivate High Quality Student Administers}

Student administrative team is also the creator of good education environment on campus. Everyone is obliged to help the school build an atmosphere that is good for students' growth. In addition to complete the "prescriptive" task assigned by various operation offices of the school, the administrators shall think hard to mobilize the enthusiasm of young students to participate in various competitions and social practice, enabling administrators to really play a role of consulting, service and leading. Therefore, to enhance the comprehensive qualities of student management team is extremely urgent. Student workers shall not only have the abilities of organization, coordination and management as well as the basic accomplishment of "being a model for others", but also shall read widely about the knowledge in terms of education, management, sociology, psychology and network technology. Thus, college leaders shall take various measures truly from manpower, finance and material. On the one hand implement the "survival of the fittest", optimize the management team of students, absorb the highly educated teachers with high title who love student work to join in, and clarify job responsibilities further. On the other hand, strengthen the training and education for administrative team, especially give given certain inclination in policy in terms of appraising, title and promotion, to relieve their worries and enhance their professional sense of belonging. Encourage student administrators strengthen scientific research, take initiative to participate in social practice, to truly become a mentor of the students, and make due contributions for students' overall healthy development.

\section{Establish the Active Service and People-Oriented Concept in Education Management for College Students}

For a long time, due to the reason of management system of higher education, the college student work tends to be of more and strong administerization, without learning about and concerning students as well as paying attention to meet students' needs. In the situation of market economy, college student workers must change their ideas, enhance service awareness, and establish the "people-oriented" concept, thus to optimize the educational environment by service. In college administration, the concept of people-oriented and studentoriented shall be reflected, and do practical things for students to solve their practical problems, such as economic difficulties, learning difficulties, confusion in life, misunderstanding of personal emotion as well as psychological disorders. Only by firmly establishing the "people-oriented" concept, can our management close to students, can we find our irreplaceable position in student management, and can the solid foundation be laid for ideological and political education. We must be engaged in the daily service from a political view, and to do the management works such as work-study program, career guidance, dormitory management and psychological counseling with love and emotion, to enable students feel the care from the Party and government from our service, and fully reflect the modern management level, thus to create a good atmosphere for students' growth, improve college students' overall quality, innovation ability and social adaptation, so that they can enter into society successfully and serve the society. We shall really establish the concept that "student is the school master", and all the work of the school should be student-centered, to serve the students better, to make college student management a powerful mechanism for cultivating students.

\section{CONCLUSION}

Under the new situation, in order to meet the needs of the development of higher education, the college administrative team shall follow the tendency, make best use of the 
circumstances based on education management, change from passive to active, confirm the realistic problem, as well as take decisive and effective measures, in order to guarantee overall improvement of students' comprehensive quality.

\section{REFERENCES}

[1] Li Shasha. Exploration of Education Management for College Students under the Influence of Network Environment [J]. Academy, 2015,30:142-143.

[2] Tong Xianghua. Do the Education Management Service for College Students Well Strictly and Practically $[\mathrm{J}]$. University Counselor, 2016,02:3-6.

[3] Zhang Peihai. Discussion on Application of Flexible Management Theory in Education Management for College Students $[\mathrm{J}]$. China Juveniles, 2015,19:251-252.

[4] Zhang Shuo. Discussion on Education Management for College Students under Background of New Media [J]. Beijing Education, Moral Education, 2012,(1).

[5] Qian Yunguang. Research on Role of Credit Archives in Education Management for College Students [J]. Journal of University of Electronic Science and Technology of China, 2012(6). 